\title{
Initiation of ribosome degradation during starvation in Escherichia coli
}

\author{
MICHAEL A. ZUNDEL, ${ }^{1}$ GEORGETA N. BASTUREA, and MURRAY P. DEUTSCHER
}

Department of Biochemistry and Molecular Biology, Miller School of Medicine, University of Miami, Miami, Florida 33136, USA

\begin{abstract}
Ribosomes are known to be degraded under conditions of nutrient limitation. However, the mechanism by which a normally stable ribosome becomes a substrate for the degradation machinery has remained elusive. Here, we present in vitro and in vivo data demonstrating that free ribosome subunits are the actual targets of the degradative enzymes, whereas $70 \mathrm{~S}$ particles are protected from such degradation. Conditions that increase the formation of subunits both in vitro and in vivo lead to enhanced degradation, while conditions favoring the presence of intact 705 ribosomes prevent or reduce breakdown. Thus, the simple formation of free $50 \mathrm{~S}$ and $30 \mathrm{~S}$ subunits is sufficient to serve as the initiation mechanism that allows endoribonuclease cleavage and subsequent ribosome breakdown.
\end{abstract}

Keywords: rRNA; endoribonuclease; ribosome subunits

\section{INTRODUCTION}

It is known that ribosomes in Escherichia coli are degraded under certain physiological conditions (Deutscher 2003). Typically, such degradation is associated with conditions in which nutrient sources are lacking, such as starvation for carbon (Jacobson and Gillespie 1968), nitrogen (BenHamida and Schlessinger 1966), phosphate (Maruyama and Mizuno 1970), or magnesium ions (McCarthy 1962). Degradation of ribosomes under starvation conditions could enable the bacterium to gain access to the large store of potential nutrients that are present in these macromolecular structures. However, details of the pathway(s) by which ribosomes are degraded, identification of the enzymes involved, and how the process is initiated have remained elusive.

In early studies, it was proposed that rRNA within ribosomes would first be cleaved endonucleolytically, generating large rRNA fragments that subsequently would be degraded to mononucleotides by exoribonucleases (Kaplan and Apirion 1975). Although attempts were made to

\footnotetext{
${ }^{1}$ Present address: United States Naval Academy, Annapolis, MD 21402, USA.

Reprint requests to: Murray P. Deutscher, Department of Biochemistry and Molecular Biology, Miller School of Medicine, University of Miami, Miami, FL 33136, USA; e-mail: mdeutsch@med.miami.edu, fax: (305) 243-3955.

Article published online ahead of print. Article and publication date are at http://www.rnajournal.org/cgi/doi/10.1261/rna.1381309.
}

identify the enzymes involved, the lack of knowledge at that time of the full repertoire of $E$. coli RNases made this difficult to accomplish (Kaplan and Apirion 1974, 1975; Cohen and Kaplan 1977). The proposed model also failed to address what signals are responsible for initiation of ribosome degradation; namely, how a normally stable ribosome becomes a substrate for the degradation machinery. Several possibilities, alone or in combination, may be envisaged. There may be a new gene product generated during starvation that destabilizes the ribosome, rendering it susceptible to degradation. Second, there could be a conformational change in the ribosome that makes it more labile and sensitive to ribonuclease activity. Third, under starvation conditions, more ribosomes may be present that are not actively translating and, as a consequence, become substrates for degradation.

The studies presented here support the last possibility. Using both in vitro and in vivo assays, we show that $70 \mathrm{~S}$ ribosomes are resistant to degradation but that $50 \mathrm{~S}$ and $30 \mathrm{~S}$ ribosome subunits are susceptible. Thus, conditions in vivo that increase the amount of ribosome subunits lead to elevation of ribosome degradation. We also provide evidence for the involvement of endoribonucleases in initiating the process of ribosome degradation by cleavage of the rRNA present in the ribosome subunits. Endoribonuclease action leads to the accumulation of discrete rRNA fragments in vivo that presumably are degraded further by exoribonucleases. 


\section{RESULTS}

\section{Degradation of ribosomes in vitro}

Ribosomes generally are quite stable in cell extracts provided that the nonspecific endoribonuclease, RNase I, is not present (Deutscher 2003, and references therein). In an attempt to identify factors that might affect ribosome stability, we first examined whether alteration of structure influenced ribosome degradation in vitro. To do this, we varied the $\mathrm{Mg}^{2+}$ concentration, an ion known to affect ribosome structure (Gorisch et al. 1976). A representative experiment is shown in Figure 1. Panel A shows the degradation of $23 \mathrm{~S}$ and $16 \mathrm{~S}$ RNAs in ${ }^{32} \mathrm{P}$-labeled ribosomes upon incubation with an extract from cells lacking RNase I carried out at 1,3 , or $5 \mathrm{mM} \mathrm{Mg}^{2+}$; the data are quantitated in Panel B. At $1 \mathrm{mM} \mathrm{Mg}^{2+}$, both $23 \mathrm{~S}$ and 16S rRNA were extensively degraded, amounting to $\sim 65 \%$ of each RNA species in $1 \mathrm{~h}$. Upon increasing the $\mathrm{Mg}^{2+}$ concentration to $3 \mathrm{mM}$, degradation was impaired, particularly for 23S RNA.

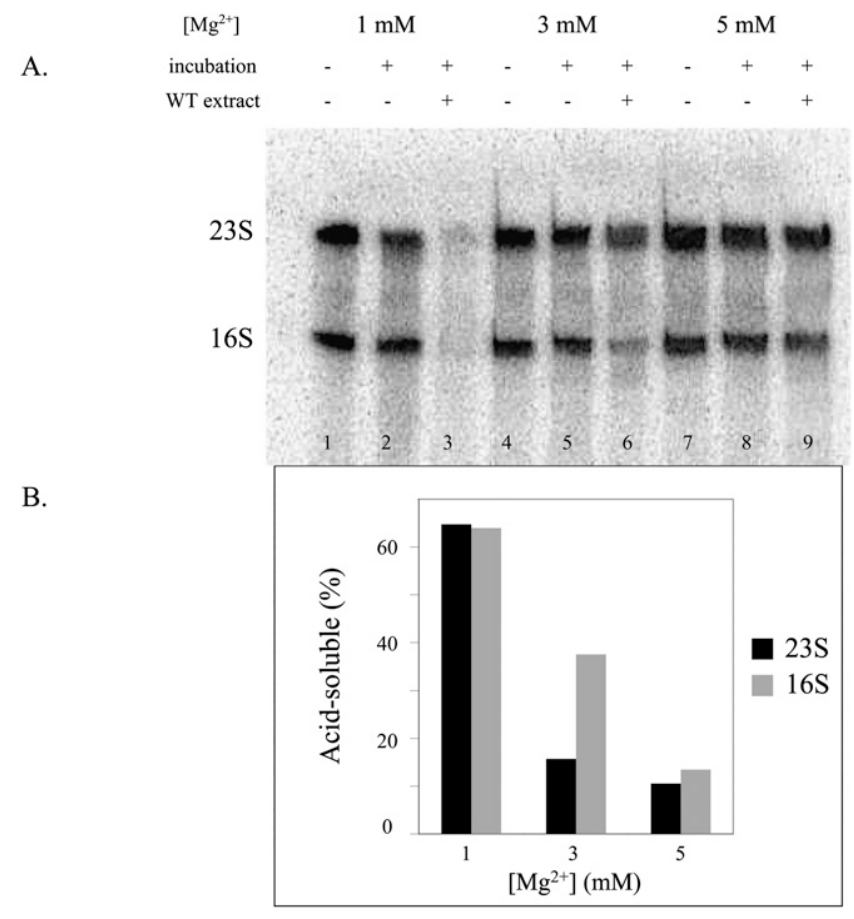

FIGURE 1. Effect of varying $\left[\mathrm{Mg}^{2+}\right]$ on ribosome degradation in vitro. Assays were performed as described in Materials and Methods with $\left[\mathrm{Mg}^{2+}\right]$ as indicated. (A) Samples were analyzed by gel electrophoresis. (Lanes 1-3) $1 \mathrm{mM} \mathrm{Mg}^{2+}$; (lanes 4-6) $3 \mathrm{mM} \mathrm{Mg}^{2+}$; (lanes 7-9) $5 \mathrm{mM} \mathrm{Mg}^{2+}$. Lanes $1,2,4,5,7,8$ contain no cell extract. Lanes 3,6,9 contain $10 \mu \mathrm{g}$ cell extract. Lanes $1,4,7$ are zero time controls. All other lanes were incubated for $60 \mathrm{~min}$ at $37^{\circ} \mathrm{C}$. (B) Densitometry was used to compare the band intensities of samples incubated with extract to the intensities of the no extract controls to obtain the percent degradation for each RNA. A representative experiment is presented. Although the absolute level of degradation varied somewhat among multiple experiments, the greatly increased degradation as the $\left[\mathrm{Mg}^{2+}\right]$ is lowered was observed reproducibly.
Thus, degradation of $16 \mathrm{~S}$ RNA in the $30 \mathrm{~S}$ subunit was reduced to $\sim 40 \%$, and that of $23 \mathrm{~S}$ RNA in the 50 S subunit was reduced to $<20 \%$. At $5 \mathrm{mM} \mathrm{Mg}^{2+}$, rRNA degradation is further decreased, amounting to only $\sim 10 \%$ of each RNA. These data show that the $\mathrm{Mg}^{2+}$ concentration can have a dramatic effect on ribosome stability in a cell extract.

$\left[\mathrm{Mg}^{2+}\right]$ is known to have multiple effects on ribosome structure. Thus, as $\left[\mathrm{Mg}^{2+}\right]$ is lowered, levels of individual subunits increase and the structures of the subunits become less compact (Gesteland 1966, Gorisch et al. 1976). To help distinguish whether formation of ribosome subunits or looser ribosome structure might be the explanation for the decreased stability of rRNA as the $\left[\mathrm{Mg}^{2+}\right]$ is lowered (Fig. 1), $50 \mathrm{~S}$ and $30 \mathrm{~S}$ subunits were isolated and their stability was directly examined in extracts at both $5 \mathrm{mM}$ and $1 \mathrm{mM}$ $\mathrm{Mg}^{2+}$ and compared to that of $70 \mathrm{~S}$ ribosomes. The data in Figure $2 \mathrm{~A}$ show that even at $5 \mathrm{mM} \mathrm{Mg}^{2+}$ the RNA in isolated subunits could be degraded by a cell extract, in contrast to $70 \mathrm{~S}$ ribosomes, which were relatively stable, as already shown in Figure 1. Quantitation of these data (Fig. 2B) showed that at $5 \mathrm{mM} \mathrm{Mg}^{2+}$, subunits were approximately fivefold more sensitive to degradation compared with 70 S ribosomes. At $1 \mathrm{mM} \mathrm{Mg}^{2+}$, also quantitated in Figure $2 \mathrm{~B}$, degradation of the subunits was even more extensive, amounting to $60 \%$ and $80 \%$ for 50 S and 30 S subunits, respectively. From these data, it is evident that subunits are inherently more sensitive to degradation, and that the increased breakdown seen at $1 \mathrm{mM} \mathrm{Mg}^{2+}$ in Figure 1 was at least partly due to their formation at this $\left[\mathrm{Mg}^{2+}\right]$. Second, the fact that the isolated subunits were even more sensitive to degradation at $1 \mathrm{mM}$ than at $5 \mathrm{mM} \mathrm{Mg}^{2+}$ suggests that loosening subunit structure may also play a role. Considering that these experiments were carried out with crude extracts, other factors may contribute to the degradation as well. Nevertheless, these data focused our attention on the increased sensitivity of ribosome subunits.

\section{Ribosome degradation in vivo}

Ribosomes are known to be stable during growth but are degraded under certain stress conditions such as nutritional deprivation (Deutscher 2003). To extend our studies to ribosome degradation in vivo, we focused on carbon starvation. In order to measure ribosome degradation during such a stress, cells were grown for many generations in M9/glucose supplemented with $\left[{ }^{3} \mathrm{H}\right]$-uridine such that all cellular RNA would be labeled (rRNA represents $\sim 85 \%$ of total RNA under these conditions) (Bremer and Dennis 1996). At mid-exponential phase, cells were collected, washed in M9 salts to remove residual glucose and $\left[{ }^{3} \mathrm{H}\right]$ uridine, and resuspended in $\mathrm{M} 9$ medium in the presence or absence of $0.4 \%$ glucose. At various times, a portion of each culture was removed and acid-soluble radioactivity determined.

A typical experiment is presented in Figure 3. The data show that cells in the presence of glucose degraded 


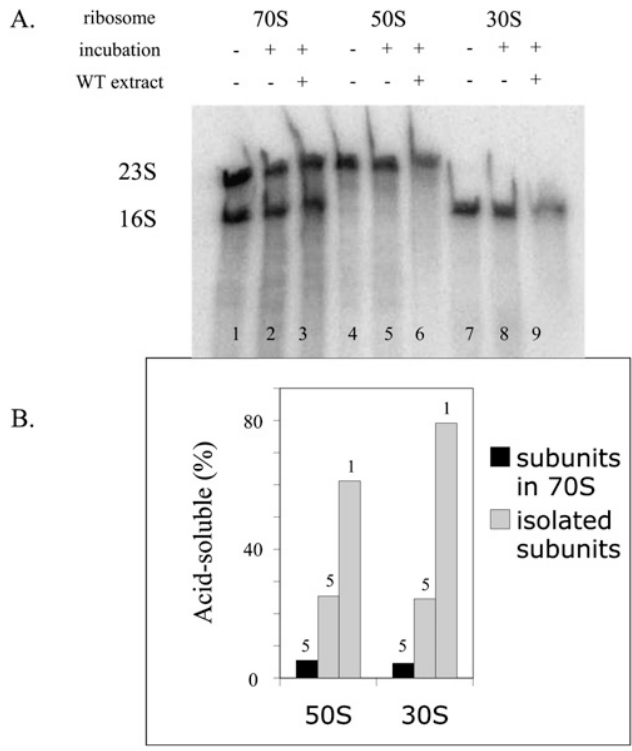

FIGURE 2. Comparison of degradation of ribosomes and ribosome subunits in vitro. (A) Assays were performed and analyzed as described in Materials and Methods at $5 \mathrm{mM} \mathrm{Mg}^{2+}$. (Lanes 1-3) $70 S$ ribosomes; (lanes 4-6) 50S subunits; (lanes 7-9) 30S subunits. Lanes $1,2,4,5,7,8$ contain no cell extract. Lanes 3,6,9 contain $10 \mu \mathrm{g}$ wild-type (WT) extract. Lanes 1,4,7 are zero time controls. All other lanes were incubated for $45 \mathrm{~min}$ at $37^{\circ} \mathrm{C}$. (B) Densitometry was used to compare band intensities of samples incubated with extract to the intensities of the zero time controls to obtain a percentage of degradation for each rRNA in 70S ribosomes or in ribosome subunits. Quantitation is also shown for a similar experiment with ribosome subunits at $1 \mathrm{mM} \mathrm{Mg}{ }^{2+}$. The number above the bars is the $\mathrm{Mg}^{2+}$ concentration used.

pre-existing RNA very slowly, or not at all, during a 3-h period. In contrast, imposition of carbon starvation led to appreciable RNA degradation amounting to $\sim 12 \%$ in $3 \mathrm{~h}$. Degradation continued for at least $24 \mathrm{~h}$ reaching close to $60 \%$ acid soluble in this time period (data not shown). Based on the amount of acid soluble radioactivity released, it is evident that destruction of ribosomes is occurring (additional evidence is presented below). Thus, this simple protocol provides a useful assay to follow the degradative process in vivo. It is important to note that this procedure measures only the smallest degradation products, i.e., mononucleotides and oligonucleotides, and this was confirmed by paper chromatography of the acid soluble material (data not shown). Large fragments generated from rRNA breakdown were detected by other methods (see below). It should also be noted that there was essentially no change in the number of viable cells in the absence of glucose based on platings for periods of up to $6 \mathrm{~h}$.

\section{Analysis of ribosome degradation during carbon starvation}

To more directly examine the fate of rRNA during carbon starvation, RNA was extracted from cells placed in the presence or absence of glucose and analyzed using gel electrophoresis. As shown in Figure 4, cells grown in the presence of glucose contained primarily $23 \mathrm{~S}$ and $16 \mathrm{~S}$ rRNA. However, in the absence of glucose, these RNAs were almost completely absent, and discrete fragments of varying sizes accumulated. These data show that rRNAs are extensively degraded during starvation and that the action of an endoribonuclease(s) likely initiates breakdown of the rRNAs. This was confirmed in a separate experiment by Northern analysis (Fig. 5) using probes against the 3 ' ends of $23 \mathrm{~S}$ and $16 \mathrm{~S}$ rRNAs. As can be seen, large fragments were generated from the $3^{\prime}$ end of each RNA that could only arise by endonucleolytic cleavage. Similarly, large fragments of each rRNA were observed with $5^{\prime}$ probes (data not shown).

Ribosomes were also examined using sucrose gradient analysis. As shown in Figure 6, in the presence of glucose, cells contained predominately $70 \mathrm{~S}$ ribosomes with only a small amount of 50S and 30S ribosome subunits present. However, after removal of glucose, there was a dramatic loss of ribosomes and a large increase in degraded material at the top of the gradient. Moreover, while 70S ribosomes decreased substantially ( $\sim 50 \%), 50$ S and 30 S subunits were eliminated entirely. These data confirm that ribosomes break down during carbon starvation, and they are consistent with the conclusion from the in vitro experiments that $50 \mathrm{~S}$ and $30 \mathrm{~S}$ subunits are the immediate substrates for the degradative process.

\section{Effect of rifampicin on ribosome degradation}

To confirm the conclusion that ribosome subunits are the substrates for the degradation machinery and also to examine whether synthesis of a new gene product might be required to signal the initiation of ribosome degradation,

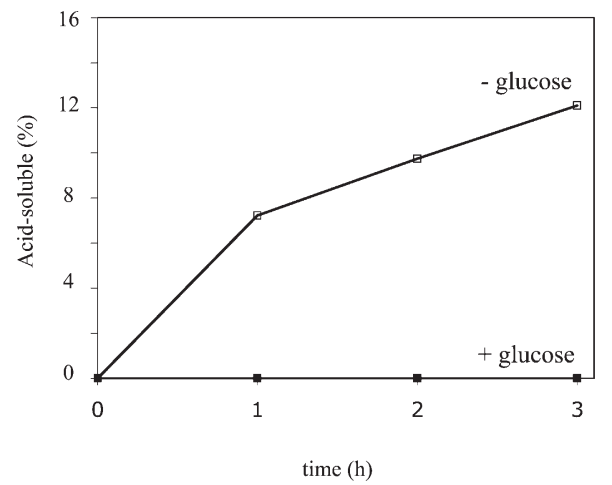

FIGURE 3. Assay of ribosome degradation during starvation for glucose in vivo. Wild-type cells were grown in the presence of $\left[{ }^{3} \mathrm{H}\right]$ uridine, followed by cell collection and resuspension in M9 medium \pm glucose, as described in Materials and Methods. Samples were taken at $0,1,2$, and $3 \mathrm{~h}$. Degradation (\%) was determined by comparing acid-soluble radioactivity to total radioactivity in the sample in the presence ( $\square$ ) or absence ( $\square$ ) of glucose. 


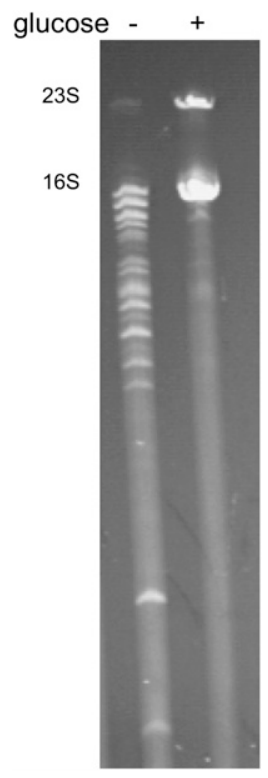

FIGURE 4. Analysis of RNA from cells undergoing carbon starvation. Total RNA was extracted from cells placed in the presence or absence of glucose for $6 \mathrm{~h}$, and RNA was quantified by $\mathrm{A}_{260}$ measurement as described in Materials and Methods. Equal amounts of RNA were loaded onto a $3 \%$ denaturing polyacrylamide gel and subjected to electrophoresis. RNA was visualized by staining with ethidium bromide and exposure to a UV lamp.

cells were starved in vivo, as described above, but with the addition of rifampicin, an antibiotic known to inhibit initiation of transcription. If a new gene product were necessary to initiate the degradative process, it might be expected that degradation would decrease or be eliminated upon rifampicin treatment. However, as shown in Figure $7 \mathrm{~A}$, degradation actually increased $\sim 40 \%$ in comparison to cells starved for glucose in the absence of rifampicin. These data indicate that synthesis of the mRNA for a new gene product is not responsible for the initiation of ribosome degradation. Moreover, they are consistent with degradation occurring at the subunit level, as translation should be reduced in the presence of rifampicin due to decreased availability of mRNA, and more ribosome subunits should be present than in the absence of rifampicin.

\section{Effect of neomycin on ribosome degradation}

To directly examine whether the level of ribosome subunits affects degradation, starvation was carried out in the presence of neomycin, an antibiotic recently shown to inhibit subunit dissociation in vivo (Borovinskaya et al. 2007). The data in Figure 7B show that in the presence of neomycin, ribosome degradation was inhibited by more than $60 \%$. Thus, maintaining ribosomes as $70 \mathrm{~S}$ particles and thereby decreasing the amount of ribosome subunits dramatically decreases the degradation of ribosomes during carbon starvation. These data support the conclusion that ribosome subunits are the immediate substrates for the initiation of ribosome breakdown.

\section{DISCUSSION}

Although the degradation of ribosomes during periods of cellular stress has been known for many years, the signal that initiates this process has until now remained elusive. Based on in vitro and in vivo analysis of this process, we propose a simple mechanism to explain how the normally stable ribosomes in growing cells become substrates for degradation. During starvation, ribosome subunits that typically are rapidly recycled into translating ribosomes during exponential growth remain idle because as the growth rate decreases, the translation machinery is less actively engaged. As shown here, ribosome subunits are inherently much more sensitive to degradation. Hence, degradation is built into the system itself, and synthesis of new components is not required. Ribosomes not engaged in translation, and consequently present as subunits, are by their nature more sensitive to degradation, and any physiological condition increasing the amount of subunits will, therefore, lead to enhanced degradation.

Support for this model comes from both in vitro and in vivo experiments. In vitro, degradation of ribosomes was greatly accelerated at lower $\left[\mathrm{Mg}^{2+}\right]$, a condition that favors separation into subunits. Moreover, direct assay of ribosome subunits showed that they were much more sensitive to breakdown by a cell extract than were 70 S ribosomes. Use of an in vivo assay for ribosome degradation confirmed these observations. Treatment of starving cells with rifampicin revealed that transcription was not necessary for ribosome degradation, and in fact, it increased the level of degradation. These data indicate first that a new gene
A.

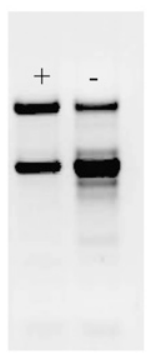

B.

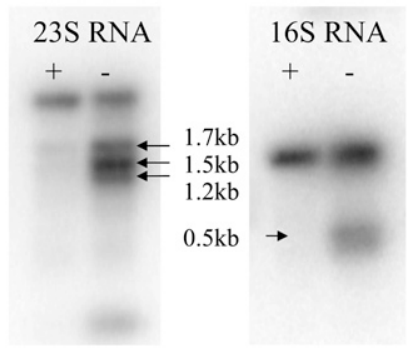

FIGURE 5. Northern blot analysis of rRNA isolated from $70 \mathrm{~S}$ ribosomes. RNA $(1 \mu \mathrm{g})$ extracted from cells grown in the presence $(+)$ or absence $(-)$ of glucose was resolved on $1.5 \%$ agarose gels, stained with ethidium bromide (panel $A$ ), transferred to nylon membranes, and probed with $23 \mathrm{~S} 3^{\prime}$-end specific or $16 \mathrm{~S} 3^{\prime}$-end specific (panel B) probes, as described in Materials and Methods. Arrows indicate the positions of major new bands. Band size was estimated from the positions of RNA standards visualized by ethidium bromide staining. Note that a product from $23 \mathrm{~S}$ degradation migrates in the position of $16 \mathrm{~S}$ RNA. 


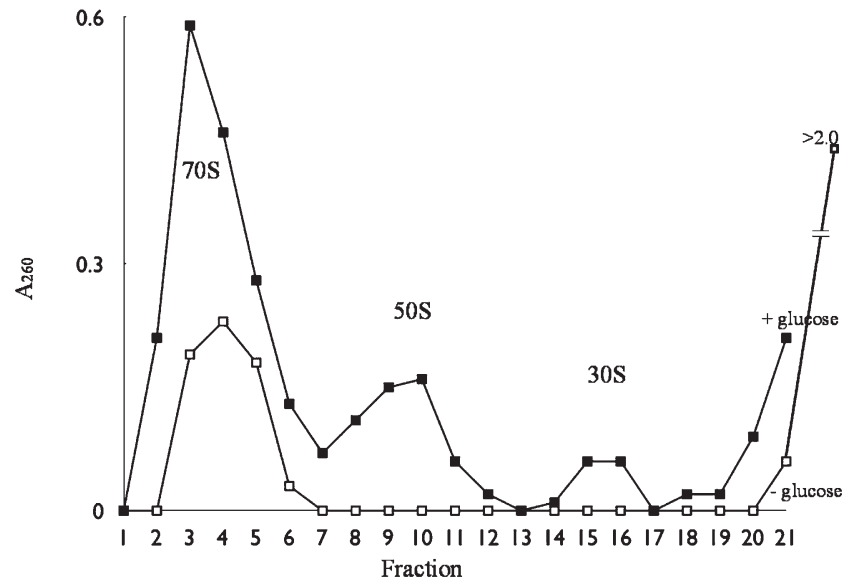

FIGURE 6. Analysis of ribosomes from cells undergoing carbon starvation. Extracts of cells grown in the presence or absence of glucose for $6 \mathrm{~h}$ were run on sucrose gradients for $15 \mathrm{~h}$ at 15,000 rpm. Equal amounts of RNA were added to the gradients. Fractions of 0.5 $\mathrm{mL}$ were collected and were analyzed for RNA content by $\mathrm{A}_{260}$. Presence ( $\square$ ) or absence ( $\square$ ) of glucose. Note the break in the scale for the top fraction of the no glucose profile.

product is not necessary for the degradation process to initiate. Second, the increased level of ribosome degradation is consistent with the mode of action of rifampicin. In its presence, fewer transcripts would be available for recycling of ribosome subunits, leading to more substrate that can be acted on by the degradative machinery. In contrast, treatment with neomycin, as a consequence of its antidissociation properties, would be expected to maintain the $70 \mathrm{~S}$ particle, thereby decreasing the amount of available substrate and leading to decreased degradation, as was found.

Most importantly, this model fits very well with our increased understanding of ribosome structure (Schuwirth et al. 2005; Korostelev and Noller 2007; Steitz 2008). The high-resolution $\mathrm{X}$-ray structures show that the majority of exposed rRNA in ribosomes is found on the subunit interfaces. Thus, the action of ribonucleases on rRNA would be favored when the $50 \mathrm{~S}$ and $30 \mathrm{~S}$ subunits are dissociated, whereas association in a $70 \mathrm{~S}$ particle during translation would serve to protect the exposed rRNA from nuclease attack.

Taken together, all of this information lends strong support to the conclusion that free subunits are the immediate substrates for ribosome degradation. They provide a simple, yet elegant mechanism, with which to signal the initiation of the degradative process. Any ribosome subunit not actively recycled into $70 \mathrm{~S}$ ribosomes potentially becomes a target for endoribonuclease action and ultimately degradation.

The model also raises a number of interesting questions for future studies. For example, what prevents the degradative machinery from acting on ribosome subunits as they recycle during the normal translation process in growing cells? One hint regarding this question comes from the work of Davis et al. (1986). They showed that translation initiation factors were not detectable during starvation. Perhaps, these and/or other protective factors could bind the subunits and inhibit nuclease action even before the reinitiation process is complete and 705 ribosomes have re-formed.

Also of considerable interest is the identification of the RNases responsible for ribosome degradation. Based on the data presented, we believe that an endoribonuclease(s) is responsible for initiating the degradative process by cleaving RNA at the subunit interfaces. Additional endoribonuclease and exoribonuclease action on the initial rRNA fragments then generates the oligoribonucleotide and mononucleotide products that we observe in the acidsoluble fraction. Studies are now in progress using purified enzymes and RNase-deficient mutant cells to identify the RNases responsible for the breakdown of rRNA.

\section{MATERIALS AND METHODS}

\section{Bacterial strains}

Strains CA244 I ${ }^{-}$and MG1655 $\mathrm{I}^{-}$were considered to be wild type for this study. The RNase $\mathrm{I}^{-}$derivatives were constructed by recombineering (Datsenko and Wanner 2000; Datta et al. 2006), and were confirmed by PCR and direct assay for RNase I.

\section{Preparation of cell extracts}

Cells grown to late exponential phase $\left(\mathrm{A}_{600} \sim 1.0\right)$ in yeast/tryptone medium at $37^{\circ} \mathrm{C}$ were cooled on ice for $20 \mathrm{~min}$ and were collected by centrifugation in a Sorvall SS34 rotor for $10 \mathrm{~min}$ at $5000 \mathrm{rpm}$ at $4^{\circ} \mathrm{C}$. The resulting cell pellets were stored at $-80^{\circ} \mathrm{C}$. Prior to use, cells were resuspended in $25 \mathrm{mM}$ Tris-Cl (pH 7.6) $400 \mathrm{mM} \mathrm{KAc}, 1$ $\mathrm{mM}$ dithiothreitol (DTT) and ruptured by two passes through an Aminco French press at 18,000 p.s.i. Cell debris was removed by centrifugation in a Sorvall SS34 rotor for $15 \mathrm{~min}$ at 15,000 rpm at $4^{\circ} \mathrm{C}$. The protein concentration of the clarified lysate was measured by the Coomassie method (Bradford 1976). Portions were frozen in liquid nitrogen and stored at $-80^{\circ} \mathrm{C}$.

\section{Preparation of $\left[{ }^{32} \mathrm{P}\right]$-labeled ribosomes}

Strain MG1655 $\mathrm{I}^{-}$was grown to mid-exponential phase in LP medium (100 mM Tris- $\mathrm{Cl}$ at $\mathrm{pH}$ 7.6, $85 \mathrm{mM} \mathrm{NaCl}, 20 \mathrm{mM} \mathrm{KCl}$, $18.6 \mathrm{mM} \mathrm{NH}_{4} \mathrm{Cl}, 0.2 \%$ casamino acids, $0.2 \%$ bactopeptone, $1 \mathrm{mM}$ $\mathrm{MgSO}_{4}, 0.2 \%$ glucose) supplemented with $1 \mu \mathrm{Ci} / \mathrm{mL}$ of $\left[{ }^{32} \mathrm{P}\right]-$ inorganic phosphate (Perkin-Elmer). Cultures were cooled on ice for $20 \mathrm{~min}$, and cells were collected by centrifugation in a Sorvall GSA rotor for $10 \mathrm{~min}$ at $5000 \mathrm{rpm}$ at $4^{\circ} \mathrm{C}$. Ribosome isolation was adapted from Powers and Noller (1991). Cell pellets were washed once in ice-cold buffer A (50 mM Tris- $\mathrm{Cl}$ at $\mathrm{pH} 7.6,10 \mathrm{mM}$ $\mathrm{MgCl}_{2}, 0.1 \mathrm{M} \mathrm{NH}_{4} \mathrm{Cl}, 6 \mathrm{mM}$ 2-mercaptoethanol, $0.5 \mathrm{mM}$ EDTA) and stored at $-80^{\circ} \mathrm{C}$. Cells were thawed on ice, resuspended in buffer A, and lysed by two passes through an Aminco French press at 18,000 p.s.i. Two units of DNase I (New England Biolabs) were added to the lysate. The lysate was then clarified by two consecutive centrifugations in a Sorvall SS34 rotor at 15,000 rpm for $15 \mathrm{~min}$ at $4^{\circ} \mathrm{C}$. The supernatant fraction was brought to $1 \mathrm{M} \mathrm{NH}_{4} \mathrm{Cl}$, layered on buffer A containing $1 \mathrm{M} \mathrm{NH}_{4} \mathrm{Cl}$ and $18 \%$ 
A.

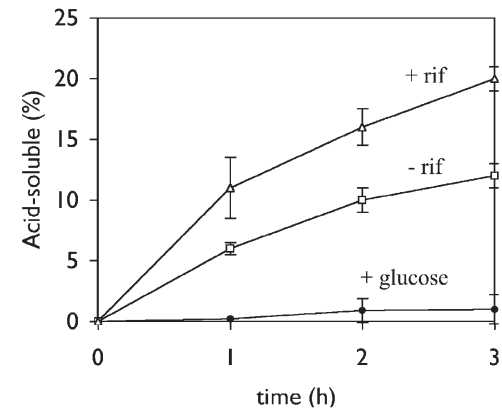

B.

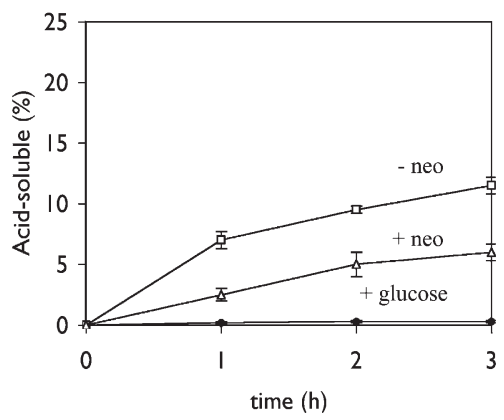

FIGURE 7. Assay of ribosome degradation during starvation for glucose in the presence of rifampicin or neomycin in vivo. $(A)$ Experiments were carried out as in Figure 3 except that rifampicin $(100 \mu \mathrm{g} / \mathrm{mL})$ was added to one culture starved for glucose. $(B)$ Experiments were carried out as in Figure 3 except that neomycin $(500 \mu \mathrm{g} / \mathrm{mL})$ was added to one culture starved for glucose.

sucrose, and spun in a Beckman ultracentrifuge at $44,000 \mathrm{rpm}$ for $19 \mathrm{~h}$ in a Beckman Ti 70.1 rotor at $4^{\circ} \mathrm{C}$. The ribosome pellets were resuspended in buffer $\mathrm{B}$ (50 $\mathrm{mM}$ Tris- $\mathrm{Cl}$ at $\mathrm{pH}$ 7.6, $10 \mathrm{mM} \mathrm{MgCl}_{2}$, $0.1 \mathrm{M} \mathrm{NH}_{4} \mathrm{Cl}, 6 \mathrm{mM}$ 2-mercaptoethanol) by gentle rocking overnight at $4^{\circ} \mathrm{C}$ and were stored in small portions at $-80^{\circ} \mathrm{C}$. Prior to use, ribosomes were layered on a $14 \%-32 \%$ sucrose gradient in buffer B plus $1 \mathrm{M} \mathrm{NH}_{4} \mathrm{Cl}$ and centrifuged in a Beckman SW28 rotor for $19 \mathrm{~h}$ at $21,000 \mathrm{rpm}$ to remove residual RNases. Fractions were collected and quantified by $\mathrm{A}_{260}$ measurement and liquid scintillation counting. Purified ribosomes were stored in small portions at $-80^{\circ} \mathrm{C}$.

\section{Preparation and electrophoresis of RNA}

RNA was extracted by phenol/chloroform treatment of $70 \mathrm{~S}$ particles purified on sucrose gradients (see below) and precipitated with ethanol. Samples were loaded either onto a $3 \%$ denaturing polyacrylamide gel or a $1.5 \%$ agarose gel; analyzed by electrophoresis at $2 \mathrm{~V} / \mathrm{cm}$ for $\sim 2 \mathrm{~h}$ or at $5 \mathrm{~V} / \mathrm{cm}$ for $1 \mathrm{~h}$, respectively; and visualized by ethidium bromide staining.

\section{Northern blot analysis}

rRNA $(1 \mu \mathrm{g})$ was resolved on a 1.5\% agarose gel in 1xTAE buffer (40 mM Tris-acetate, $1 \mathrm{mM}$ EDTA) and transferred to a nylon membrane by downward capillary transfer for $3 \mathrm{~h}$ using $1 \mathrm{xTAE}$ as the transfer solution. DNA oligonucleotide probes complementary to either the $3^{\prime}$-end of the 16S RNA ( $5^{\prime}$-aaggaggtgatccaaccgca- $\left.3^{\prime}\right)$ or the $3^{\prime}$-end of the 23S RNA ( $5^{\prime}$-aaggttaagctcacggttc- $\left.3^{\prime}\right)$ were $\left[{ }^{32} \mathrm{P}\right]$-labeled at their $5^{\prime}$-ends by $\mathrm{T} 7$ polynuclotide kinase. Probes were allowed to anneal to the transferred RNA by overnight incubation in ExpressHyb hybridization solution (Clontech), and the detected bands were visualized by PhosphorImager (Molecular Dynamics) analysis.

\section{In vitro assays for ribosome degradation}

Reaction mixtures $(100 \mu \mathrm{L})$ contained $25 \mathrm{mM}$ Tris- $\mathrm{Cl}(\mathrm{pH} 7.6)$, $400 \mathrm{mM}$ KAc, $1 \mathrm{mM}$ DTT, $2 \mu \mathrm{g}\left[{ }^{32} \mathrm{P}\right]$-labeled ribosomes, and $10 \mu \mathrm{g}$ cellular extract. Samples usually were incubated for $60 \mathrm{~min}$ at $37^{\circ} \mathrm{C}$. For subsequent electrophoresis, $10 \mu \mathrm{L}$ were removed and mixed with $10 \mu \mathrm{L}$ of loading buffer $(10 \mathrm{mM}$ Tris-Cl at $\mathrm{pH}$ 7.6, $10 \mathrm{mM}$ EDTA, 1\% SDS, 40\% glycerol, $0.1 \%$ diethylpyrocarbonate [DEPC], $0.25 \%$ bromophenol blue), vortexed, and boiled for 2 min before loading on a $3 \%$ denaturing polyacrylamide gel. Samples were subjected to electrophoresis at $200 \mathrm{~mA}$ for 3 h. The gel was then placed on Whatman filter paper and directly used for autoradiography.

\section{In vivo assay for ribosome degradation}

A single colony was inoculated into $2 \mathrm{~mL}$ of $\mathrm{M} 9 / 0.2 \%$ glucose medium. After overnight growth, $100 \mu \mathrm{L}$ was inoculated into $100 \mathrm{~mL}$ of $\mathrm{M} 9 / 0.2 \%$ glucose supplemented with $1 \mu \mathrm{Ci} / \mathrm{mL}$ of $\left[{ }^{3} \mathrm{H}\right]$-uridine (GE) and 0.1 $\mathrm{mM}$ uridine. Cultures were grown to midexponential phase. Cells were collected by centrifugation for $10 \mathrm{~min}$ in a Sorvall SS34 rotor . The cell pellet was washed once in M9 salts and resuspended in $5 \mathrm{~mL}$ of M9 salts. Half was inoculated into a culture of $45 \mathrm{~mL}$ of $\mathrm{M} 9 / 0.4 \%$ glucose and $0.1 \mathrm{mM}$ uridine, while the rest was inoculated into $45 \mathrm{~mL}$ of M9 salts and $0.1 \mathrm{mM}$ uridine, lacking glucose. In some assays, antibiotics were also added at the indicated concentrations. $\mathrm{A}_{600}$ readings were taken to monitor growth. At indicated times, 500 $\mu \mathrm{L}$ portions were removed from the culture and treated with $4 \mathrm{M}$ formic acid (Cohen and Kaplan 1977). After $15 \mathrm{~min}$ on ice, samples were centrifuged at maximum speed for $15 \mathrm{~min}$ in a Fisher bench top microcentrifuge at $4^{\circ} \mathrm{C}$. Half of the supernatant fraction was removed and neutralized with $1 \mathrm{M}$ Tris. Ten milliliters of scintillation fluid was added, and samples were counted in a scintillation counter to determine acid-soluble radioactivity.

\section{Sucrose gradient analysis}

Cells were grown as above for the in vivo assay except that $\left[{ }^{3} \mathrm{H}\right]-$ uridine was omitted. After $6 \mathrm{~h}$ of incubation, cell extracts were made as described above. RNA amounts were determined by $\mathrm{A}_{260}$ measurement. Equal amounts of RNA were layered onto 5\%-20\% sucrose gradients containing $20 \mathrm{mM}$ Tris- $\mathrm{Cl}$ ( $\mathrm{pH}$ 7.6), $15 \mathrm{mM} \mathrm{Mg}$ $(\mathrm{OAc})_{2}, 100 \mathrm{mM} \mathrm{NH}_{4}$ Ac, $1 \mathrm{mM}$ DTT in DEPC-treated $\mathrm{H}_{2} \mathrm{O}$ (Wada et al. 2000) and centrifuged for $15 \mathrm{~h}$ at 15,000 rpm in a Beckman SW41 rotor at $4^{\circ} \mathrm{C}$. Gradients were analyzed as described in the section for obtaining $\left[{ }^{32} \mathrm{P}\right]$-labeled ribosomes.

\section{AKNOWLEDGMENTS}

We thank Drs. Chaitanya Jain, Kenneth Rudd, and Arun Malhotra for helpful discussions and reading of the manuscript. This work was supported by Grant GM16317 from the National Institutes of Health.

Received September 19, 2008; accepted February 10, 2009.

\section{REFERENCES}

Ben-Hamida, F. and Schlessinger, D. 1966. Synthesis and breakdown of ribonucleic acid in Escherichia coli starving for nitrogen. Biochim. Biophys. Acta 119: 183-191. 
Borovinskaya, M.A., Pai, R.D., Zhang, W., Schuwirth, B.S., Holton, J.M., Hirokawa, G., Kaji, H., Kaji, A., and Cate, J.H.D. 2007. Structural basis for aminoglycoside inhibition of bacterial ribosome recycling. Nat. Struct. Mol. Biol. 14: 727-732.

Bradford, M.M. 1976. A rapid and sensitive method for the quantitation of microgram quantities of protein utilizing the principle of protein-dye binding. Anal. Biochem. 72: 248-254.

Bremer, H. and Dennis, P.P. 1996. Modulation of chemical composition and other parameters of the cell by growth rate. In Escherichia coli and salmonella (ed. F.C. Neidhardt), pp. 15531569. ASM Press, Washington, DC.

Cohen, L. and Kaplan, R. 1977. Accumulation of nucleotides by starved Escherichia coli cells as a probe for the involvement of ribonucleases in ribonucleic acid degradation. J. Bacteriol. 129: 651-657.

Datsenko, K.A. and Wanner, B.L. 2000. One-step inactivation of chromosomal genes in Escherichia coli K-12 using PCR products. Proc. Natl. Acad. Sci. 97: 6640-6645.

Datta, S., Costantino, N., and Court, D.L. 2006. A set of recombineering plasmids for gram-negative bacteria. Gene 379: 109-115.

Davis, B.D., Luger, S.M., and Tai, P.C. 1986. Role of ribosomes degradation in the death of starved Escherichia coli cells. J. Bacteriol. 166: 439-445.

Deutscher, M.P. 2003. Degradation of stable RNA in bacteria. J. Biol. Chem. 278: 45041-45044.

Gesteland, R.F. 1966. Unfolding of Escherichia coli ribosomes by removal of magnesium. J. Mol. Biol. 18: 356-371.

Gorisch, H., Goss, D.J., and Parkhurst, L.J. 1976. Kinetics of ribosome dissociation and subunit association studied in a light-scattering stopped-flow apparatus. Biochemistry 15: 5743-5753.
Jacobson, A. and Gillespie, D. 1968. Metabolic events occuring during recovery from prolonged glucose starvation in Escherichia coli. J. Bacteriol. 95: 1030-1039.

Kaplan, R. and Apirion, D. 1974. The involvement of RNase I, RNase II, and polynucleotide phosphorylase in the degradation of stable ribonucleic acid during carbon starvation in Escherichia coli. J. Biol. Chem. 249: 149-151.

Kaplan, R. and Apirion, D. 1975. The fate of ribosomes in Escherichia coli cells starved for a carbon source. J. Biol. Chem. 250: 1854-1863.

Korostelev, A. and Noller, H.F. 2007. The ribosome in focus: New structures bring new insights. Trends Biochem. Sci. 32: 434-441.

Maruyama, H. and Mizuno, D.I. 1970. Ribosome degradation and the degradation products in starved Escherichia coli I. Comparison of the degradation rate and of the nucleotide pool between Escherichia coli B and Q-13 strains in phosphate deficiency. Biochim. Biophys. Acta 199: 159-165.

McCarthy, B.J. 1962. The effects of magnesium starvation on the ribosome content of Escherichia coli. Biochim. Biophys. Acta 55: $880-888$.

Powers, T. and Noller, H.F. 1991. A functional pseudoknot in $16 \mathrm{~S}$ ribosomal RNA. EMBO J. 10: 2203-2214.

Schuwirth, B.S., Borovinskaya, M.A., Hau, C.W., Zhang, W., VilaSanjurjo, A., Holton, J.M., and Cate, J.H. 2005. Structures of the bacterial ribosome at $3.5 \AA$ resolution. Science 310: 827-834.

Steitz, T.A. 2008. A structural understanding of the dynamic ribosome machine. Nat. Rev. Mol. Cell Biol. 9: 242-253.

Wada, A., Mikkola, R., Kurland, C.G., and Ishihama, A. 2000. Growth phase-coupled changes of the ribosome profile in natural isolates and laboratory strains of Escherichia coli. J. Bacteriol. 182: 28932899. 

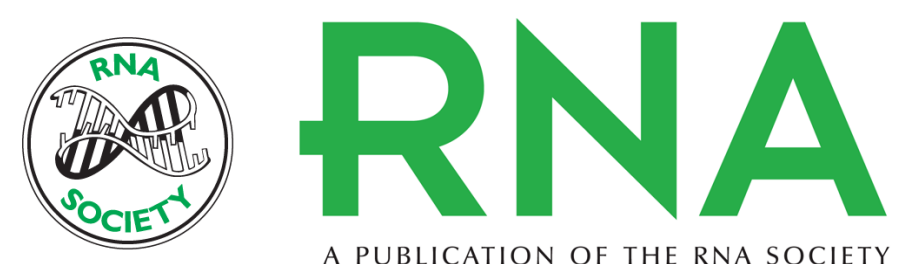

A PUBLICATION OF THE RNA SOCIETY

\section{Initiation of ribosome degradation during starvation in Escherichia coli}

Michael A. Zundel, Georgeta N. Basturea and Murray P. Deutscher

RNA 2009 15: 977-983 originally published online March 26, 2009

Access the most recent version at doi:10.1261/rna.1381309

References This article cites 20 articles, 9 of which can be accessed free at:

http://rnajournal.cshlp.org/content/15/5/977.full.html\#ref-list-1

License

Email Alerting Receive free email alerts when new articles cite this article - sign up in the box at the Service top right corner of the article or click here.

To subscribe to $R N A$ go to:

http://rnajournal.cshlp.org/subscriptions 